\title{
Paradigms and theories in water governance: the case of South Africa's National Water Resource Strategy, Second Edition
}

\author{
Richard Meissner ${ }^{1,2}$ \\ ${ }^{1}$ Council for Scientific and Industrial Research (CSIR), South Africa, P.O. Box 395, Pretoria, 0001, \\ ${ }^{2}$ Centre for Water Resources Research, University of KwaZulu-Natal, Private Bag X01, Scottsville, 3209, South Africa, http://cwrr.ukzn.ac.za/
}

\begin{abstract}
This paper indicates the influence of paradigms and theories on the development of South Africa's National Water Resource Strategy, Second Edition. Five paradigms exist: positivism, postpositivism, interpretivism/constructivism, critical theories and the participatory paradigm. I use the PULSE ${ }^{3}$ framework for analysis that I developed to analyse the NWRS2. I found that positivism is the dominant paradigm influencing the NWRS2. I furthermore analyse the strategy through two alternative theories: agential power and the ambiguity theory of leadership. These theories are interpretivist/constructivist type theories. My argument is for the integration of paradigms through the utilisation of analytic eclecticism. In light of positivism's dominance, I conclude that water research can be more innovative through the integration of paradigms and alternative theories.
\end{abstract}

Keywords: water governance, paradigm, theory, policy, leadership theory, power

\section{INTRODUCTION}

I argue that paradigms and theories are the foundations of water governance because they constitute the development of governance along dominant discursive thinking. This argument has implications for the practical application of water governance. Change in society does not occur automatically; it is usually caused by an event or by someone. A person or persons operate from a certain cognitive outlook and with an intention in mind. Individuals play an important role in governance with feedbacks into policy processes (Meissner and Jacobs, 2014). Individuals can be citizens, public officials and private sector practitioners, arguing from a certain approach to ameliorate a problem (e.g. Meissner, 2004). Approaches can be as holistic as possible, but if they do not rely on an eclectic foundation with multiple paradigms and theories, they are unlikely to provide the necessary understanding for practitioners. Complex challenges demand the integration of diverse expertise and ingenuity (Meissner and Jacobs, 2014).

In this paper I analyse the South African Department of Water and Sanitation's (DWS, previously the Department of Water Affairs) National Water Resource Strategy, second edition (NWRS2) (DWA, 2013) to understand which paradigm(s) and theories influence it. I start this paper with a description of the PULSE ${ }^{3}$ framework for analysis, its rationale and components. I will also reflect on paradigms and theories; what they are and why they are important elements in the NWRS2. I will then analyse the strategy using the framework. A discussion and conclusion end the article.

\section{PULSE $^{3}$}

The rationale for $\mathrm{PULSE}^{3}$ (people understanding and living in a sustained environment) that I developed (Meissner, 2014a, b)

\footnotetext{
* To whom all correspondence should be addressed

e-mail: RMeissner@csir.co.za

Received: 24 November 2014; accepted in revised form 11 November 2015
}

rests on the argument that single paradigmatic and theoretical explanations have difficulty explaining fundamental social processes, like behaviour and contradiction. The cube denotes three forces: thinking, shaping and change. Individuals think, shape and cause changes. Organisations and the natural environment shape and affect changes impacting on human society. Resource management challenges are to an extent wicked problems. These have multiple dimensions of information and formulation, clients and decision makers with conflicting values and confusing ramifications. They also appear repeatedly (Rittel and Weber, 1973; Jentoft and Chuenpagdee, 2009). To make sense of wicked problems a single paradigm or theory is insufficient. A single theory cannot account for everything (Albert and Buzan, 2013). Multiple theories are necessary to enrich explanations (Walt, 2005).

Humans employ cognitive processes to work out rules, patterns and relationships that govern complex relationships with each other and reality (McGann, 2008). Determining rules, patterns and relationships researchers need paradigms and theories to guide action (Guba, 1990). I refer to paradigms as research traditions, consisting of metatheoretical assumptions about knowledge production (Sil and Katzenstein, 2010). Theories explain the connections between phenomena through simplifications consisting of interrelated assumptions, definitions, ideas and proposals (Kerlinger, 1986; Koh, 2013). In the next section I outline PULSE's's components: a paradigm assessment tool, analytic eclecticism and theories for practice (Meissner, 2014a, b).

\section{Paradigm assessment}

The purpose of the paradigm assessment is to assist practitioners to identify where scientific knowledge focuses its attention and the potential pitfalls for practicalities. The difference between positivism, postpositivism, interpretivism/constructivism, critical theories and the participatory paradigm (Lincoln et al., 2011; Hobson and Seabrooke, 2007) is the foundation of PULSE ${ }^{3}$ 's paradigm assessment component. The five paradigms differ according to various dimensions (see Tables 1 and 2). The differentiation of the five paradigms can help 
TABLE 1

The five paradigms summarised

\section{Positivism}

Action is structured, linear and has a cause and effect manner (Eisner, 1990).

There is an objective, apprehensible reality (Ponterotto, 2005).

\section{Postpositivism}

Action is structured linear and has a cause and effect manner (Eisner, 1990). There is an objective reality that we can only imperfectly apprehend (Ponterotto, 2005).

\begin{tabular}{l|l|l|} 
Interpretivism/constructivism & Critical theories & $\begin{array}{l}\text { Participatory } \\
\text { paradigm }\end{array}$ \\
$\begin{array}{l}\text { Action is contained in the lived experiences } \\
\text { from the point of view of those who experi- } \\
\text { ence it. There is a multitude of apprehensi- } \\
\text { ble and equally valid realities (Ponterotto, } \\
\text { 2005). }\end{array}$ & $\begin{array}{l}\text { The status quo needs } \\
\text { to be disrupted and } \\
\text { changed. Researchers } \\
\text { tasks are to emanci- } \\
\text { pate and transform } \\
\text { reality (Ponterotto, } \\
\text { 2005). }\end{array}$ & $\begin{array}{l}\text { Action is the result of } \\
\text { the researcher and the } \\
\text { research participant's } \\
\text { interaction during the } \\
\text { research process to } \\
\text { improve the human } \\
\text { condition. There is a } \\
\text { participative reality } \\
\text { with a link between } \\
\text { subjective and objec- } \\
\text { tive reality (Lincoln et } \\
\text { al., 2011). }\end{array}$ \\
&
\end{tabular}

TABLE 2

The metatheoretical elements at a glance

\begin{tabular}{|c|c|}
\hline $\begin{array}{l}\text { Knowledge generation } \\
\text { metatheoretical elements }\end{array}$ & Explanation \\
\hline Ontology & $\begin{array}{l}\text { Reality's nature is paramount. For instance, is the reality separate or inseparable from the } \\
\text { researcher? }\end{array}$ \\
\hline Epistemology & $\begin{array}{l}\text { There is a relationship between the researcher and the reality being researched. Does an objective } \\
\text { reality exist or is the reality constructed through the researcher's reference frame? }\end{array}$ \\
\hline Research object & The research object can have qualities existing independently from the researcher. \\
\hline Method & $\begin{array}{l}\text { This is the research process and can be done through statistical analyses, laboratory experiments, } \\
\text { case studies, ethnographic studies and so on. }\end{array}$ \\
\hline Theory of truth & $\begin{array}{l}\text { Research investigates truths in knowledge statements. Does the statement represent a one-to-one } \\
\text { mapping between reality and research statements or is truth found in the struggle for equality and } \\
\text { social justice? }\end{array}$ \\
\hline Validity & $\begin{array}{l}\text { Validity deals with certainty in that data truly measure reality or there are defensible claims depend- } \\
\text { ing on the research method. }\end{array}$ \\
\hline Reliability & Can the researcher reproduce research results or do researchers realise their subjectivity? \\
\hline Training & Training can be technical and quantitative and/or qualitative. \\
\hline Agency metatheoretical elements & Explanation \\
\hline Organising question & $\begin{array}{l}\text { Examples of organising questions are: who governs and who benefits, who acts and what are the } \\
\text { consequences of their actions? }\end{array}$ \\
\hline Unit of Analysis & Units of analyses can be international organisations, governments, regulations or individuals. \\
\hline Prime empirical focus & Researchers can focus on political order, economic development or social transformation. \\
\hline Locus of agency & Bottom-up or top-down. \\
\hline Level of analysis & Systemic or complex/holistic. \\
\hline Ontology & $\begin{array}{l}\text { Agential, structuralist or structurationist. Reality can come about due to individuals or government } \\
\text { actions. }\end{array}$ \\
\hline $\begin{array}{l}\text { Recommendations based on specific } \\
\text { theoretical assumptions }\end{array}$ & Recommendations can be positivist, interpretivist or subjectivist. \\
\hline Voice & The researcher's voice informs decision makers. The voice can be disinterested or activist. \\
\hline Ethics & $\begin{array}{l}\text { For positivists, their research studies nature; they are not interested in how nature influences human } \\
\text { populations. For critical theorists, research investigates issues for developing a just society. }\end{array}$ \\
\hline $\begin{array}{l}\text { Hegemony or the influence of the } \\
\text { researcher over others }\end{array}$ & $\begin{array}{l}\text { For positivists, the research and not the researcher should be influential. Interpretivists seek input } \\
\text { into practices and offer to change existing paradigms. }\end{array}$ \\
\hline $\begin{array}{l}\text { Axiology or how researchers act based } \\
\text { on their research. }\end{array}$ & $\begin{array}{l}\text { For interpretivists, propositional knowledge is instrumentally valuable for social emancipation, } \\
\text { while critical theorists seek to change issues and social institutions. }\end{array}$ \\
\hline $\begin{array}{l}\text { Action or the nature of research } \\
\text { products. }\end{array}$ & $\begin{array}{l}\text { For positivists, researchers must remain strictly objective and are not concerned about actions. For } \\
\text { participatory paradigm researchers, their research can mandate training in political action. }\end{array}$ \\
\hline $\begin{array}{l}\text { Control or who dictates how the } \\
\text { research is produced and used? }\end{array}$ & $\begin{array}{l}\text { For interpretivists, the research results are shared between the researcher and the participant. } \\
\text { Positivists conduct research without the inputs from participants or society. }\end{array}$ \\
\hline
\end{tabular}

Sources: Weber 2004; Hobson and Seabrooke 2007; Lincoln et al. 2011. 
profiling policies. This will determine the extent of the endeavour's positivism, postpositivism, interpretivism/constructivism, critical theory and participatory paradigm stance. The paradigm assessment tool considers the way in which knowledge is generated for a policy and the agency it contains.

Knowledge generation deals with how the policy had been developed through research or how its supportive arguments are structured. I define agency as any acts discussed within the policy involving some form of operationalised human action or recommendations (Meissner, 2014a, b). The following excerpt from the NWRS2 indicates the difference between knowledge generation (in italics) and agency (in bold).

\section{South Africa has to prioritise, considering the mix of options available to supply the huge water demands for equitable allocation for development and economic growth. The country will thus consider other potential sources, which include water re-use, desalina- tion, groundwater utilisation, water conserva- tion and water demand management meas- ures, rain water harvesting, recovering water from acid mine drainage, and the import of water intensive goods (DWA 2013: iii).}

Table 2 explains the metatheoretical elements under knowledge generation and agency. Taking the various meta-theoretical elements from the five paradigms for both knowledge and agency produces a matrix consisting of 105 elements.

To determine a paradigm's influence, I employ a simple scoring system. The paradigm underpinning the knowledge or action is scored against the presence or absence of metatheoretical elements. A value of 0 equals absent; 1 equals present. If more than one element is present I award a score of 1 to both.

\section{Analytic eclecticism}

Elsewhere I give a rendition of analytic eclecticism's nature (Meissner, 2015) as outlined by Sil and Katzenstein (2010) and will therefore not discuss it in full in this article. Briefly explained, where paradigms have blind spots, analytic eclecticism holds promise in ameliorating the situation (Sil and Katzenstein, 2010). The purpose of analytic eclecticism is to avoid paradigmatic limitation. Arguing from a particular paradigm can become an obstacle to understanding even if it gives powerful insights. To use analytic eclecticism prior assumptions need to be problematised. Research questions are developed and boundaries for investigation set according to prior assumptions. Researchers conduct their investigations to reflect such assumptions. What is necessary for this article is that researchers are not always driven by what they observe but rather what was written or said before because they rely on prior assumptions from dominant paradigms. Problems' complexities are the victims since other paradigms are not considered. The remedy is analytic eclecticism assisting researchers in understanding inherently complex social, political (Katzenstein and Okawara, 2001/02), environmental and psychological processes in governance.

\section{Theories for practice}

For analytic eclecticism one also needs a repertoire of theories. Numerous theories explain actors, relations and phenomena (Lemert, 2013). 'Theories are heuristic for generating.. . strategies and for dealing with anticipated and empirically encountered problems' (Rowell, 1984: 1). Every strategy has limitations and makes sense in its own context. Although theories are circumstance-specific they are all meaningful. If a theory or set of theories are dominant within a discourse, it can lead participants to adopt its prescriptions in the form of dogma to guide practice (Rowell, 1984). This can have implications for water governance because, should certain theories dominate, it can influence practitioners to adopt their prescriptions without considering other ideas or assumptions. Let me explain this using a definition of governance. Governance is not the domain of governments only. Governance rests on the interaction between different actors to create opportunities and solve problems (Rhodes, 1996; Kooiman et al., 2008; Meissner and Jacobs, 2014). Governments are therefore not the only sources of governance and governance is not only about dealing with solving problems through governmental regulations. Scientists can also govern. They are not innocent bystanders in the research process, often playing an active part in water resource governance (e.g. Meissner, 2015). Since scientists received their training based on certain paradigms, how they do research will likely be influenced by such exposure. When one or more paradigm-specific theories dominate, policy recommendations will likely follow such paradigms and theories. Should this be the case, 'appropriate empirical variables' will miss the 'multiplicity of different types of evidence to be appreciated' (Kurki, 2006: 195). This missing of other evidence is something analytic eclecticism tries to avoid. In the South African water discourse adoption of theoretical prescriptions exist in the form of integrated water resource management, adaptive management and complexity (Meissner et al., 2013; Meissner and Funke, 2014). What other empirical variables outside these theories are scientists missing? To answer this question one needs a repertoire of theories. A repertoire of theories makes it possible to identify other empirical variables in the South African water sector. I will employ agential power (Hobson, 2000) and the ambiguity theory of leadership (Alvesson and Spicer, 2011) as two theories to further explain the NWRS2 after analysing it.

\section{PARADIGM ASSESSMENT OF THE NWRS2}

The NWRS2 is a strategic document produced by the Department of Water Affairs, now the DWS. The purpose of the strategy 'is to ensure that national water resources are managed towards achieving South Africa's growth, development and socio-economic priorities in an equitable and sustainable manner over the next five to 10 years' (DWA 2013: 1). The NWRS2 has a significant status in that it is a 'legal instrument' for implementation of the National Water Act (No. 36 of 1998). Because of this legal status, it is 'binding on all authorities and institutions implementing the Act' (DWA, 2013: 1). The strategy has 16 chapters covering South Africa's national strategic imperatives: water resources planning, infrastructure development and management; water resource protection; equitable water allocation; water conservation and demand management; institutional arrangements; regulation of the water sector; managing water resources for climate change; international cooperation; financial management; monitoring and information management; research and innovation; skills and capacity and emerging policy issues and the implementation of the strategy (DWA, 2013).

This section of the paper consists of two parts; the first discussing the meta-theoretical assumptions around knowledge generation and the second the assumptions on agency. 
Throughout the discussion I will use examples from the strategy to illustrate the points made. These examples are from the NWRS2 and they are descriptive. An argument might arise that these descriptive issues need to be first stated before doing the assessment. I argue that the descriptive issues indicate the nature and extent of certain paradigmatic metatheoretical elements of the NWRS2. My focus is the application of the PULSE ${ }^{3}$ framework using the NWRS2 and not the NWRS2 as the lens through which to look at government-led water governance.

\section{Knowledge generation}

The paradigm assessment indicates that the NWRS2 is underpinned by positivism (Fig. 1). The graph is a visual representation of the application of the paradigm assessment after I had identified the presence or absence of metatheoretical elements in the NWRS2. The bars and their values indicate to what extent certain metatheoretical assumptions are present or absent in the NWRS2. In other words, during the analysis of the NWRS2 I identified, using metatheoretical assumptions, which paradigm was present or absent. The numbers above each bar represent how many times the metatheoretical assumptions appear in the strategy. The meta-theoretical assumptions that scored the highest are ontology, epistemology, research object and theory of truth. They were followed by method, validity, reliability and training. The total score for knowledge generation was 150 . The total score for the secondhighest paradigm (interpretivism/constructivism) was 22 .

Two explanations could shed light on the high score that positivism received. The first explanation relates to the nature of the resource the strategy deals with. The second, and related to the first, is the type of science that deals with water planning.

Water is a chemical compound that is necessary for the production of goods and services in all spheres of the economy. Water is also considered to have 'great power' for human beings because it shapes, renews and nourishes life on earth. We see water as the planet's life blood (Gillings, 2010). The importance of water for the economy and as a life sustaining substance is exemplified in the vision, goal, principles and objectives of the NWRS2. The vision is 'sustainable, equitable and secure water for a better life and environment for all.' The goal to achieve this vision is that 'water is efficiently and effectively managed for equitable and sustainable growth and development.' The centrality of water is further exemplified in the strategy's objectives. Three objectives support the country's social and economic goals and the sustainable management of water resources. Water is essential for development and the eradication of poverty and inequality. Water also needs to contribute to the economy and job creation and water has to be protected, developed, used, conserved, controlled and managed in an equitable and sustainable manner (DWA, 2013: 12). The central message is the betterment of citizens' lives and for this we need to manage water resources in a particular manner. The economy and job creation take centre stage making the strategy quite anthropocentric instead of ecocentric. What is also noteworthy is the way in which water is used for the advancement of citizens' lives. South Africa will manage it in a sustainable manner and it will control the water resources inside its territory (DWA, 2013). This is not to say that the environment is kicked out, so to speak. Positivism is not anti-ecocentric.

Sustainable development resonates strongly throughout the NWRS2. The philosophical foundations of sustainable development were laid in 1987 by the World Commission on
Environment and Development (the Brundtland Commission). According to the Brundtland Report, humanity has the ability to make development sustainable - to ensure that it meets the needs of the present without compromising the ability of future generations to meet their own needs (UN, 1987). According to Beder (2001), governments incorporate economic positivism into sustainable development. Beder (2001) further contends that sustainable development prioritises the importance of equity within and between generations, while economic positivism highlights economic efficiency. The NWRS2 combines equity and efficiency in this manner. It is therefore not sustainable development that is positivist. It is sustainable development's incorporation into economic positivism that gives sustainable development a positivist flavour because through the sustainable development practices South Africa will better management its water resources.

Positivistic planning is the strategy's foundation. In positivism 'science and technology are combined to establish a model with clearly defined goals...objectives with measurable achievement of goals, the collection of information on possible alternatives as well as associated costs and benefits and a selection of alternatives or set of alternatives that bring about maximal achievement of public goals at minimal costs' (Berke, 2002: 23 cited in Depalma, 2009). The growth and development goals of the NWRS2 are in line with the National Development Plan (NDP) noting that: 'Current planning assumes that it will be possible to achieve an average reduction in water demand of 15 percent below business-as-usual levels in urban areas over the period leading to 2030' (NPC, 2011). Water supply is an important issue for the strategy. Yet, water will not only be supplied through the construction of water infrastructure. Water supply alternatives include desalination through a variety of technological means such as membranes. Annexure C of the NWRS2 outlines the National Desalination Strategy. Other alternatives are the re-use of municipal wastewater for urban and industrial uses and treatment of acid mine drainage. To achieve this, a National Strategy for Water Re-Use is explained in Annexure D. In both these strategies cost and benefit are important in the rationale behind their implementation. For instance, the desalination strategy notes that: 'Desalination is already being implemented in South Africa and is cost-effective compared to the alternatives' (DWA, 2013).

Also noteworthy in the NWRS2 is the utilisation of technical reports or scientific studies to substantiate arguments or generate ideas. These reports and studies are from the natural sciences, steeped in positivism, and include some prominent names in water research. Dr Peter Ashton conducted research on South Africa's freshwater resources (e.g. Ashton, 2007), transboundary rivers (e.g. Kistin and Ashton, 2008) and water quality issues (e.g. Ashton, 2010). The NWRS2 also cites work by Prof. Roland Schulze from the University of KwaZulu-Natal. Schulze is known for his work on climate change (e.g. Schulze, 2011a; Stuart-Hill and Schulze, 2010) and adaptive management (e.g. Schulze, 2011b). Then there is Nel et al.'s (2011) Atlas of Freshwater Ecosystem Priority Areas in South Africa.

Not only does the strategy reference the Water Research Commission's (WRC) published research, the WRC is also a strategic partner in the research and development of water issues. The strategy notes that: 'More than half of water research activities, funded and coordinated through the [WRC] are conducted by universities, science councils, organs of state, the private sector, water utilities and other agencies...' (DWA, 2013: 94). Policy development is influenced by a variety of actors, scientists (Meissner et al., 2013) and technical personnel 


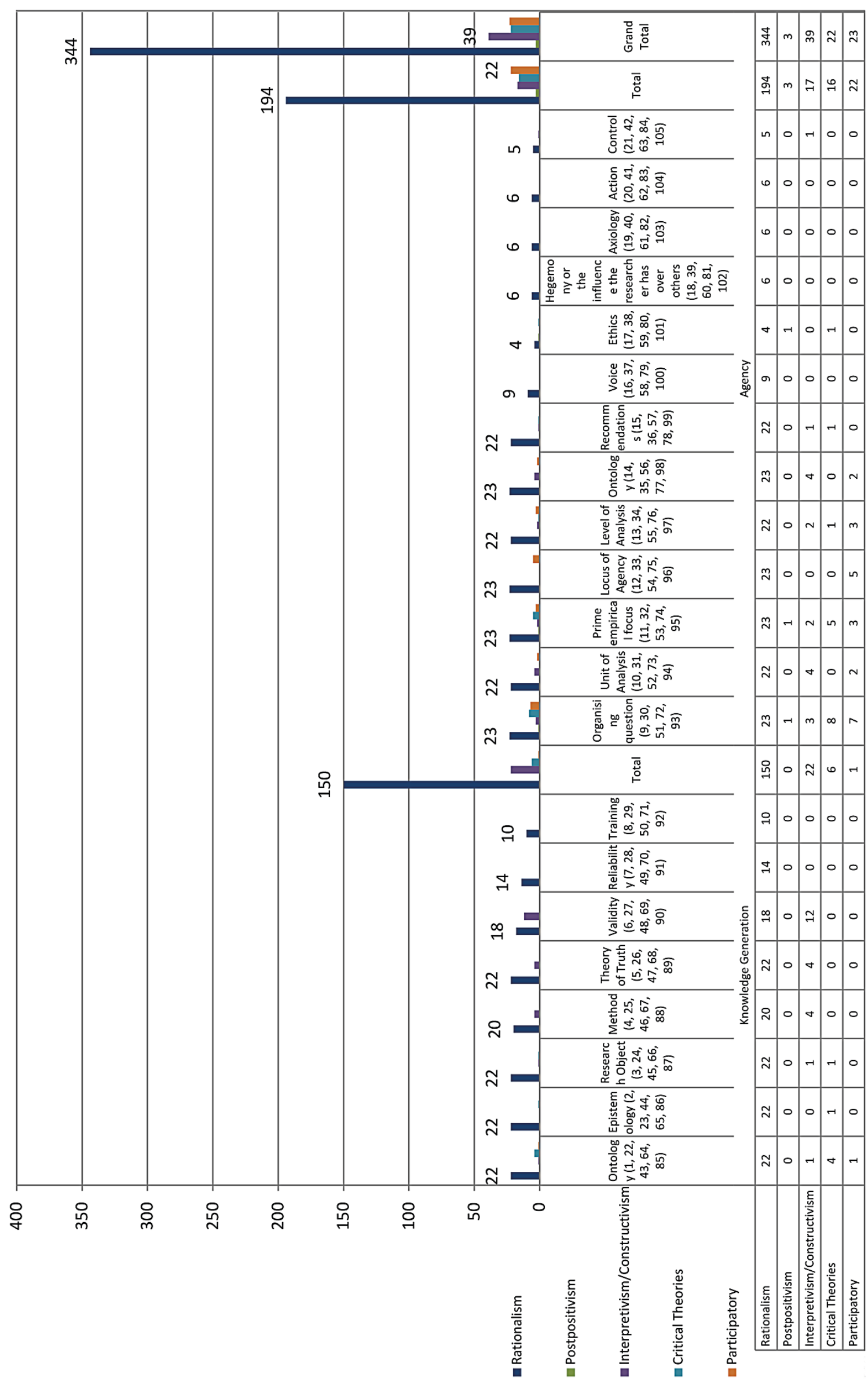

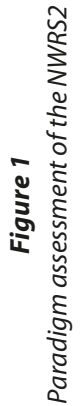


from institutions like Sasol (DWA, 2013). The analysis of the knowledge used in the NWRS2 is mainly from the natural sciences where positivism is the dominant paradigm in generating knowledge.

Regarding this, Kratochwil (2007) asserts that various sciences developed because they did not take the scientific method too seriously. For the scientists that produced the scientific studies used to produce the NWRS2, scientific progress was possibly not the main concern. What was important for them was to show, through scientific evidence, the nature of the reality of the country's water resources and how to manage that reality.

\section{Agency}

Positivism also scored high under the agency component. The meta-theoretical assumptions that scored the highest were organising question, unit of analysis, prime empirical focus, locus of agency, level of analysis, ontology and recommendations. This high score is probably due to the nature of the agent that developed the strategy: the government and more specifically the DWS that utilised knowledge generated by the positivist paradigm. From the strategy it is clear 'who governs and who benefits' (organising question); the government governs and the rest of society benefits. This becomes clear in the following quote: 'This Strategy responds to priorities set by Government within the NDP and National Water Act imperatives that support sustainable development' (DWA, 2013: iii). The NWRS2 places a lot of attention on structures of rule like the National Water Act (No. 36 of 1998) (RSA, 1998), constitutional rights, the Water Services Act (No. 108 of 1997) (RSA, 1997) and the Southern African Development Community's (SADC) Revised Protocol on Shared Water Courses (DWA, 2013). The prime empirical focus of the strategy is the supply of order and welfare maximisation (Hobson and Seabrooke, 2007). Good governance is put forward to ensure that unsustainable water management does not lead to risks to employment, the environment, human health and political stability. One of the strategy's most important priorities is the management of water for electricity generation (DWA, 2013). The locus of agency is top-down (Hobson and Seabrooke, 2007). Here the DWA (2013: 1) states that the NWRS2 has a focus that is particular, 'but not exclusive ... on the role of the State, specifically the Department of Water and [Sanitation] (as water sector leader)...'

The promotion of the hydraulic mission as a type of ideology that leads to a dominant belief system where hydraulic engineering is pivotal (Turton, 2000 cited in Turton and Meissner, 2002: 39) is quite evident in the NWRS2. Although the strategy emphasises that the country '....move beyond "traditional engineering solutions" of infrastructure development...' it calls for '.... a multitude of strategies, including [WCWDM]..., further utilisation of groundwater, desalination, water re-use, rain water harvesting and treated acid mine drainage.' The WCWDM stance is prioritised and is likely to lead, according to the strategy, to the postponement of water engineering infrastructure, the mitigation of climate change, the supporting of economic growth and enough water for equitable allocation. The WCWDM approach rests on a positivist paradigm emphasising water resource distribution and consumer demand management (DWA, 2013). The NWRS2 utilises knowledge developed by Seago and McKenzie (2007) to indicate the benefits and practical interventions of WCWDM. The interventions include, among others: water quality management, social awareness and education, water resource rehabilitation, dam storage optimisation, alien vegetation removal, pressure management and metering retro-fitting, effective pricing, polluter pays, regulations and so on (DWA, 2013). These, except for social awareness and education, fall within the positivist paradigm.

\section{THE NWRS2 THROUGH THE LENS OF ANALYTIC ECLECTICISM}

The positivism of the NWRS2 shows paradigmatic limitation. That is not to say that we understand less about water resources in South Africa and the relationship between the resource and the functioning of society. The research conducted by water scientists over the years has generated useful insights. The research has also provided pragmatic ideas on how to create opportunities and ameliorate problems. Even so, the prior assumptions about what type of knowledge is relevant (e.g. hydrological data and the reconciliation of systems) (DWA, 2013), which actors are relevant (engineers and hydrologists) and the structures of rule, such as the National Water Act (No. 36 of 1998), are the foundations on which knowledge is generated and agency affected. The problem with this arrangement is that after a while the assumptions are considered law-like. The assumptions are not questioned and they become the central canon of knowledge generation; they can become dogma. Because the NWRS2 is built on positivism this reinforces this law-like assertive character. The result is a likely increase in arguments' sophistication in influencing the recommendations Government has to implement. This is possibly the reason for the focus on technical solutions such as WCWDM, desalination and water re-use (DWA, 2013).

Other paradigms' metatheoretical assumptions are present within the NWRS2. When the strategy discusses support to municipalities it states that this will be done through: 'Mobilisation of partnerships and support from the private sector in respect of technical expertise, funding, training and implementation' (DWA, 2013: 58). Elsewhere it states that: 'Education and awareness is not the function of national government only; and all sector institutions, private sector organisations and civil society should be institutionalising the promotion of [WCWDM]' (DWA, 2013: 58). These two examples are indications of agency based on the participatory paradigm that supplies order and welfare maximisation by political elites (Hobson and Seabrooke, 2007; Meissner and Ramasar, 2014), practitioners from different spheres of society and researchers. This means that there is not a paradigm shift from positivism to the participatory paradigm, but rather an evocation of participatory paradigm assumptions on the achievement of technical aspects.

Should we discard the paradigmatic ways in which the NWRS2 is constructed? Not at all! What needs to happen is to investigate the relationship between alternative paradigms and how these relate to the various issues raised throughout the strategy. Alternative theories could assist in this matter.

\section{THEORIES FOR PRACTICE}

The NWRS2 constitutes a certain understanding, management and 'control' of the country's water resources. The strategy reduces the country's water resources to the processes as outlined by the water cycle in Annexure B (DWA, 2013). The strategy elaborates on this reductionist notion showing that it is 
possible to manage water by controlling behaviour using technological solutions and education and awareness. This reductionism is influenced by positivism and vice-versa. The strategy is further influenced by positivist (natural) scientists. I bracket the 'natural' because natural scientists dominate the water research landscape (Meissner et al., 2013). Social scientists can also argue from a positivist paradigm. How can we widen our understanding of the NWRS2 and its implementation?

Although the NWRS2 highlights participation of the private sector, the overall impression is that of a strategy directed by Government through positivism. Two theories that can bring about a deeper understanding of the situation are agential power (Hobson, 2000; Meissner, 2004; Hobson and Seabrooke, 2007; Meissner, 2014c) and the ambiguity theory of leadership (Alvesson and Spicer, 2011). Both theories look at societal processes and actors from an interpretivist/constructivist and participatory paradigm perspective.

\section{Agential power}

Agential power gives actors agency to influence their environment and each other (Hobson and Seabrooke, 2007). Agential power falls into three categories: domestic, international and reflexive agential power. I will focus on reflexive agential power because it deals with the relationship between societal actors (i.e. governance). Reflexive agential power is the 'ability of the state to embed itself in a broad array of social forces...' including class and normative structures. This increases its governing capacity since the state is less isolated from society and other actors. By widening its network of collaboration the state can increase its power (Hobson, 1997; Hobson, 2000; Meissner, 2004). When an actor is embedded within social structures it is bounded within society. State and society cannot be separated (Hobson, 1997: 236). If a state does not routinely negotiate with groups in society, it has despotic power and low capacity to govern (Hobson, 1997; Hobson, 2000). Hobson (1997: 238) notes that '...strength can be achieved only through effective politics; and this ultimately requires a strong dose of cooperation as opposed to abrasion with society.' Depolitisation is not an option where there is a seeming lack of state capacity, but an increase in value allocation efficiency (Easton, 1985) with and through society. To consistently resist civil pressures, in light of state capacity, is a sign of weakness not strength. This brings to the fore the notion of competitive-cooperation in which two actors get along with each other because their conflict is not zero-sum, but collectively beneficial (Huntington, 1991 in Hobson, 1997).

\section{Ambiguity theory of leadership}

The ambiguity theory of leadership states that versions of leadership are invented or constructed by people. This construction takes place when they draw on their assumptions, expectations, selective perceptions, sense-making and imaginations of leadership (Alvesson and Spicer, 2011). Leadership exists only as a perception and not a viable scientific construction (Calder, 1977: 202 cited in Alvesson and Spicer, 2011). Leadership therefore varies from person to person and context to context. Leadership is often incoherent and complex. Because of the different meanings of leadership, it is difficult to say exactly what leadership is. Leadership is an ambiguous and contradictory construct. The different meanings and constructs bring out the potential for leadership's ambiguous interpretations, understandings and experiences. Ambiguity and fragmentation is at the centre of the leadership process. As such people use the concept to reach certain desirable goals. These objectives could include: attributing responsibility to senior managers for numerous outcomes, boosting the identity of managers and creating faith that leadership is a panacea. The utility of the concept is a lever to create certain things, fostering a belief that leadership can do wonders, which is not the case according to Alvesson and Spicer (2011). The attributed meanings of leadership are important sources of ambiguity. The sources of ambiguous meaning of leadership are leaders, their followers and the context in which leaders and followers operate. Leaders are not always sure about what it means to do leadership, and whether what they are doing is actually leadership. Followers interpret different acts as leadership. The context promotes different understandings and ideas about the meaning of leading (Alvesson and Spicer, 2011).

\section{DISCUSSION AND CONCLUSION}

Based on agential power and the ambiguity theory of leadership, how can South Africa enhance the NWRS2's implementation? How the Strategy was developed and how it will be executed goes hand-in-glove. It is here where agential power starts to shed light on an alternative understanding of the NWRS2 and its execution.

That the NWRS2 relies on scientific studies gives the strategy credence based on the standing of the scientists. This is also the case where the NWRS2 invokes IWRM in combination with the developmental state. Other 'scientific' concepts like 'virtual water' (DWA, 2013), or the volume of water needed to produce import and export goods and foodstuffs, (Allan, 2001; Meissner, 2003; Earle et al., 2010; DWA, 2013), also give credibility to the NWRS2. It is therefore not entirely impossible that the NWRS2 is a reaction to current trends in the global water governance discourse. This is evident where IWRM is combined with the developmental state. The developmental state plays a central role in managing water resources that play a critical role in equitable social and economic development (Van Koppen and Schreiner, 2014). It is as if the authors of the NWRS2 were including IWRM as a management practice to align it with global practices, despite IWRM's limitations (e.g. Merrey, 2008; Claassen, 2013; Van Koppen and Schreiner, 2014). It is therefore not only prominent scientists that have power, the concepts they develop can also influence policy. This influence emanates from within South African and internationally.

Since agential power gives actors the ability to influence their environment and each other (Hobson, 1997, 2000), the NWRS2 indicates a measure of agential power. This is due to the strategy's regulatory foundations and cost-benefit arguments. Through the NWRS2, however, the DWS embeds itself into a certain structural and material domain; positivism and the knowledge produced by natural scientists. The NWRS2 is bounded to these structures and cannot be separated from them and cost-benefit analysis. The NWRS2 therefore exhibits despotic power (Hobson, 1997, 2000) that could potentially influence Government's governing capacity to implement the strategy. It can be said that the NWRS2, and by extension the DWS, has low reflexive agential power (Hobson, 2000; Meissner, 2004). How can this reflexive agential power be enhanced? According to the theory of agential power, an actor can influence its governing capacity positively if it widens its network of collaboration (Hobson, 2000). When drafting the NRWS2, DWS received a number of written submissions from 
non-state actors (e.g. non-governmental organisations, interest groups, businesses and individuals) (DWA, 2013). At first glance this would appear like higher reflexive agential power. It is arguably not, because not all South African citizens and interest groups submitted submissions. Also, not all individuals are literate and were therefore able to submit submissions. It can be argued that only a certain class of society submitted submissions (i.e. the capitalist class). The list of submissions indicates that it was organised entities that dominated with a handful of individuals. The written submissions show that the DWS asked for these indicating that Government is at the top of a hierarchy when consulting other non-state actors. It is therefore a case of the DWS governing and other societal actors benefiting.

The ontology of the South African water sector is a bit more complicated than the structuralism and materialism influencing the NWRS2. Although equity and the environment are mentioned as priorities (DWA, 2013), the ontological complexity of issues is downplayed. It is good that the water cycle is mentioned for an advanced understanding of the country's water resources. Nevertheless, the NWRS2 sketches an objective reality separated from individuals. It becomes more complicated when people see themselves participating, in one way or another, in the water cycle. For instance, an Eskom engineer has a certain view where the utility's power stations are located in the water cycle and how it influences the cycle through the use of water for power generation and cooling (i.e. thermodynamics). An individual from a rural community that is reliant on a river for drinking water will view her place in the water cycle differently to that of the engineer. Her reality is different in that she would want a more reliable source of water to live a healthy life. It is these subjective notions of reality that is lacking in the NWRS2. Even so, and in all fairness, the NWRS2 is a strategy and not a specific tactic to tackle a specific problem. In this vein embeddedness is possible by linking with communities and the research/scientific structures that generate knowledge through alternative paradigms and on issues that do not fit neatly with positivism.

This highlights the notion of collective beneficiation (Huntington, 1991; Hobson, 1997) where government structures engage with communal and natural and social scientific structures to widen the scope of issues impacting on the country's water. This beneficiation can be achieved through formal and informal negotiations with other structures as well.

This raises the issue of leadership. The NWRS2 notes that the DWS is leading its implementation. The DWS (DWA, 2013: 102, 1) states that: 'This NWRS2 provides the Strategy for how the water sector and its key institutions will achieve the strategic objectives' with the Department as the 'water sector leader.' This creates a sense of the DWS being the most dominant actor in water governance arrangements, a notion that can 'hide' the importance of other actors, like private sector companies and water user associations. Since people define leadership as they see fit and depending on their context (Alvesson and Spicer, 2011), individuals could view the DWS's leadership of the NWRS2 in different ways. During fieldtrips we undertook for our various research projects, it is not uncommon to hear people say that government should provide them with water. I have never encountered an individual saying an irrigation board, or water user association or traditional leader, for that matter, should provide water. This indicates government's leadership role being constructed as that of 'ultimate water provider'. It is also common to hear non-governmental organisations complaining that government is not doing enough to supply water and protect the environment. This construction is of government as 'absconder of water provision responsibilities' and 'irresponsible environmental custodian.' This indicates the ambiguity of government's perceived leadership roles in the water sector. Something also has to be said about followers. Followers, whoever they may be, use their different meanings of leadership as levers to achieve or gain something (Alvesson and Spicer, 2011). An interest group using a specific meaning of leadership might do so to increase its standing in society. Individuals could also use the meanings to vent their frustration to a situation or, at the extreme, mask ideological commitments such as contempt for a Black-majority controlled government and its entities. It will not be possible to correctly interpret why people construct certain meanings of leadership. Yet, it is important for DWS officials to know that there is not just one warranted meaning of leadership and that people's different meanings could have real-world influences on governing.

In conclusion, water governance is not only about the interactive relationship between different actors to create opportunities and solve problems. Water governance is also about the way in which actors see the water governance landscape, filter it through paradigms and theories, and interpret what is happening and what the causal mechanisms are that influence the practice of water governance. What I am trying to say is that water governance does not only involve regulatory structures, the involvement of actors and material aspects. The ideas generated by these actors through cognitive processes like theory formation and theory application are one of the most fundamental causal mechanisms of water governance. Because of the dominance of certain paradigms and theories, I believe that the South African water sector might not be as innovative as it should be. In other words, it is not living up to its potential to bring to the fore innovative ways of governing water resources.

\section{REFERENCES}

ALBERT M and BUZAN B (2013) International relations theory and the "social whole": Encounters and gaps between IR and Sociology. Int. Polit. Sociol. 7 117-135. http://dx.doi.org/10.1111/ips.12013

ALLAN JA (2001) The Middle East Water Question: Hydropolitics and the Global Economy. I.B. Tauris, London.

ALVESSON M and SPICER A (eds) (2011) Metaphors We Lead By: Understanding Leadership in the Real World. Routledge, London and New York.

ASHTON PJ (2007) Riverine biodiversity conservation in South Africa: current situation and future prospects. Aquat. Conserv. Mar. Freshwater Ecosyst. 17 (5) 441-445. http://dx.doi.org/10.1002/ aqc. 886

ASHTON PJ (2010) The demise of the Nile crocodile (Crocodylus niloticus) as a keystone species for aquatic ecosystem conservation in South Africa: The case of the Olifants River. Aquat. Conserv. Mar. Freshwater Ecosyst. 20 (5) 489-493. http://dx.doi.org/10.1002/ aqc. 1132

BEDER S (2001) Equity or efficiency. Engineers Australia May 200139.

BERKE PR (2002) Does sustainable development offer a new direction for planning? Challenges for the twenty-first century. J. Plann. Lit. 17 (1) 21-36. http://dx.doi.org/10.1177/088122017001002

CALDER BJ (1977) An attribution theory of leadership. In: Staw BM and Salanick GR (eds) New Directions in Organizational Behaviour. St Clair, Chicago.

CLAASSEN M (2013) Integrated water resource management in South Africa. Int. J. Water Gov. 1 (3) 323-338. http://dx.doi. org/10.7564/13-IJWG12

DEPALMA MM (2009) Principles of sustainable development in 
the comprehensive plan for Gainesville, Florida. Master's thesis, University of Florida, Gainesville.

DWA (DEPARTMENT OF WATER AFFAIRS, SOUTH AFRICA) (2013) National Water Resource Strategy, June 2013, Second Edition. Department of Water Affairs, Pretoria. 200 pp.

EARLE A, JÄGERSKOG A and ÖJENDAL J (2010) Introduction: setting the scene for transboundary water management approaches. In: Earle A, Jägerskog A, Öjendal J (eds.) Transboundary Water Management: Principles and Practice. Earthscan, London. http:// dx.doi.org/10.1002/9780470935132.ch1

EASTON D (1985) Political science in the United States: Past and present. Int. Polit. Sci. Rev. 6 (1) 133-152. http://dx.doi. org/10.1177/019251218500600113

EISNER EW (1990) The meaning of alternative paradigms for practice. In: Guba EG (ed.) The Alternative Paradigm Dialog. Sage Publications, Newbury Park, CA.

GILLINGS A (2010) How Earth Made Us: Water. BBC, London.

GUBA EG (1990) The alternative paradigm dialog. In: Guba EG (ed.) The Alternative Paradigm Dialog. Sage Publications, Newbury Park.

HOBSON JM (1997) The Wealth of States: A Comparative Sociology of International Economic and Political Change. Cambridge University Press, Cambridge.

HOBSON JM (2000) The State and International Relations. Cambridge University Press, Cambridge. http://dx.doi.org/10.1017/ CBO9780511612442

HOBSON JM and SEABROOKE L (2007) Everyday IPE: revealing everyday forms of change in the world economy. In: Hobson JM and Seabrooke L (eds) Everyday Politics of the World Economy. Cambridge University Press, Cambridge.

HUNTINGTON SP (1991) Transnational organisations in world politics. In: Little R and Smith M (eds.) Perspectives on World Politics. Routledge, London.

JENTOFT S and CHUENPAGDEE R (2009) Fisheries and coastal governance as a wicked problem. Mar. Polic. 33 (4) 553-560. http:// dx.doi.org/10.1016/j.marpol.2008.12.002

KATZENSTEIN PJ and OKAWARA N (2001/02) Japan, Asian-Pacific security, and the case for analytical eclecticism. Int. Secur. 26 (3) 153-185.

KERLINGER FN (1986) Foundation of Behavioural Research ( $3^{\text {rd }}$ edn) Holt, Rienhart \& Winston, New York.

KISTIN EJ and ASHTON PJ (2008) Adapting to change in transboundary rivers: an analysis of treaty flexibility on the Orange-Senqu River basin. Water Resour. Dev. 24 (3) 385-400. http://dx.doi. org/10.1016/j.lisr.2012.09.003

KOH K (2013) Theory-to-research-to-theory strategy: A research-based expansion of radical change theory. Libr. Inform. Sci. Res. 35 (1) 33-40. http://dx.doi.org/10.1016/j.lisr.2012.09.003

KRATOCHWIL FV (2007) Evidence, inference, and truth as problems of theory building in the social sciences. In: Lebow RN and Lichbach MI (eds.) Theory and Evidence in Comparative Politics and International Relations. Palgrave MacMillan, New York.

KURKI M (2006) Cause of a divided discipline: Rethinking the concept of cause in international relations. Rev. Int. Stud. 32 (2) 189-216. http://dx.doi.org/10.1017/S026021050600698X

LEMERT C (2013) Social Theory: The Multicultural, Global and Classic Readings. Westview Press, Boulder, CO.

McGANN K (2008) The Story of Maths: The Language of the Universe. BBC Four Documentary, London.

MEISSNER R (2003) Regional food security and virtual water: Some natural, political and economic implications. In: Hoekstra AY (ed.) Virtual Water Trade: Proceedings of the Expert Meeting on Virtual Water Trade. Research Report Series No. 12. IHE Delft, Delft.

MEISSNER R (2004) The transnational role and involvement of interest groups in water politics: a comparative analysis of selected Southern Africa case studies. D.Phil. dissertation, University of Pretoria.

MEISSNER R, FUNKE N, NIENANBER S and NTOMBELA C (2013) The status quo of research on South Africa's water management institutions. Water SA 39 (5) 721-731. http://dx.doi.org/10.4314/ wsa.v39i5.17

MEISSNER R (2014a) Paradigms and theories in water governance: The case of South Africa's National Water Resource strategy,
Second Edition. CSIR Publication Number: CSIR/NRE/WR/ IR/2014/0076/A. CSIR, Pretoria.

MEISSNER R (2014b) Paradigms and theories influencing a selected section of global water governance: The case of the UNDP's Water and Ocean Governance focus area. CSIR Publication Number: CSIR/NRE/WR/IR/2014/0077/A. CSIR, Pretoria.

MEISSNER R (2014c) Who wants to be an agent? A framework to analyse water politics and governance. Water $S A 40$ (1) 1-9. http:// dx.doi.org/10.4314/wsa.v40i1.1

MEISSNER R and JACOBS I (2014) Theorising complex water governance in Africa: the case of the proposed Epupa Dam on the Kunene River. Int. Environ. Agreem. Polit. Law Econ. 14 (2) 1-28. http:// dx.doi.org/10.1007/s10784-014-9250-9

MEISSNER R and FUNKE N (2014) The politics of establishing catchment management agencies in South Africa: the case of the Breede-Overberg Catchment Management Agency. In: Huitema D and Meijerink S (eds.) The Politics of River Basin Organisations: Coalitions, Institutional Design Choices and Consequences. Edward Elgar Publishing, Cheltenham. http:// dx.doi.org/10.4337/9781782549222.00013

MEISSNER R and RAMASAR (2014) Governance and politics in the upper Limpopo River basin, South Africa. GeoJournal 80 (4) 689-709.

MEISSNER R (2015) The governance of urban wastewater treatment infrastructure in the Greater Sekhukhune District Municipality and the application of analytic eclecticism. Int. J. Water Gov. 3 (2) 79-110. http://dx.doi.org/10.7564/14-IJWG55

MERREY DJ (2008) Is normative integrated water resources management implementable? Charting a practical course with lessons from Southern Africa. Phys. Chem. Earth 33 899-905. http://dx.doi. org/10.1016/j.pce.2008.06.026

NATIONAL PLANNING COMMISSION (NPC) (2011) National Development Plan: Vision for 2030. National Planning Commission, Pretoria.

NEL JL, DRIVER A, STRYDOM WF, MAHERRY A, PETERSEN C, HILL L, ROUX DJ, NIENABER S, VAN DEVENTER H, SWARTZ E and SMITH-ADAO LB (2011) Atlas of freshwater ecosystem priority areas in South Africa: Maps to support sustainable development of water resources. WRC Report No. TT 500/11. Water Research Commission, Pretoria.

PONTEROTTO JG (2005) Qualitative research in counceling psychology: A primer on research paradigms and philosophy of science. J. Couns. Psychol. 52 (2) 126-136. http://dx.doi. org/10.1037/0022-0167.52.2.126

RHODES RAW (1996) The new governance: Governing without government. Polit. Stud. 44 (4) 652-667. http://dx.doi. org/10.1111/j.1467-9248.1996.tb01747.x

RITTEL HWJ and WEBBER MM (1973) Dilemmas in a general theory of planning. Polic. Sci. 4 (2) 155-169. http://dx.doi.org/10.1007/ BF01405730

ROWELL JA (1984) Many paths to knowledge: Piaget and science education. Stud. Sci. Educ. 11 (1) 1-25. http://dx.doi. org/10.1080/03057268408559912

RSA (REPUBLIC OF SOUTH AFRICA) (1997) Water Services Act. Act 108 of 1997. Government Printer, Cape Town. 70 pp.

RSA (REPUBLIC OF SOUTH AFRICA) (1998) National Water Act. Act 36 of 1998. Government Printer, Cape Town. 101 pp.

SCHULZE RE (2011a) Approaches towards practical adaptive management options for selected water related sectors in South Africa in a context of climate change. Water SA 37 (5) 621-646. http://dx.doi. org/10.4314/wsa.v37i5.1

SCHULZE RE (2011) A 2011 Perspective on climate change and the South African water sector. WRC Report No. 1843/2/11. Water Research Commission, Pretoria.

SEAGO CJ and McKENZIE RS (2007) An assessment of non-revenue water in South Africa. WRC Report No. TT300/07. Water Research Commission, Pretoria.

SIL R and KATZENSTEIN PJ (2010) Beyond paradigms: analytic eclecticism in the study of world politics. Palgrave Macmillan, Houndmills, Basingstoke.

STUART-HILL SI and SCHULZE RE (2010) Does South Africa's water law and policy allow for climate change adaptation? Clim. Dev. 2 (2) 128-144. http://dx.doi.org/10.3763/cdev.2010.0035 
TURTON A (2000) Water and Sustainable Development: Southern Perspective. Encyclopedia of Life Support Systems (EOLSS) UNESCO-EOLSS, Oxford.

TURTON A and MEISSNER R (2002) The hydrosocial contract and its manifestation in society: A South African case study. In: Turton A and Henwood R (eds.) Hydropolitics in the Developing World: A Southern African Perspective. African Water Issues Research Unit, Pretoria.

UN (UNITED NATIONS) (1987) Our Common Future: Report of the World Commission on Environment and Development. United Nations, New York.
VAN KOPPEN B and SCHREINER B (2014) Moving beyond integrated water resource management: developmental water management in South Africa. Int. J. Water Resour. Dev. http://dx.doi.org/10.1080/07 900627.2014.912111

WALT SM (2005) The relationship between theory and policy in international relations. Ann. Rev. Polit. Sci. 8 23-48. http://dx.doi. org/10.1146/annurev.polisci.7.012003.104904

WEBER R (2004) The rhetoric of positivism versus interpretivism: A personal view. MIS Q. 28 (1) iii-xii. 